\title{
Sol Viñolo: huellas editoriales para la memoria de un ser extraordinario
}

\author{
Gustavo Sora* \\ *Investigador de Conicet en el Idacor / prof titular del depto de \\ Antropología Ffyh - UNC. E-mail: gustavosora@gmail.com
}

El lunes 17 de mayo del corriente año, la antropóloga Sol Viñolo (29) y el realizador visual Agustín Burgos (31) murieron atropellados por la inaudita violencia de Alan Amoedo (27), quien alcoholizado manejaba a toda velocidad por la Avenida Circunvalación de la ciudad de Córdoba, pasando vehículos por la banquina.

Un par de semanas antes, Sol había quebrado un obstáculo significativo para el progreso de toda carrera científica: la publicación, sometiendo sus manuscritos a la evaluación de pares. Sol escribía sin parar, con vocación, sensibilidad, búsqueda de estilo, pulsiones de una lectora voraz que avanzaba a paso firme en la costura de su propio proyecto creador. Era en extremo exigente consigo misma. Como a algunos de los iniciantes, el pasaje a la edición (compleja transmutación de escritor a autor, donde el juego no es apenas hacerse un nombre sino que perdure en el tiempo) en ella se figuraba como un gran salto en alto: mostrarse, darse a conocer; no hacerlo en modo automático (como incita el burocrático frenesí de la cultura evaluativa en las ciencias contemporáneas); hacerlo como era antaño, de forma tal que se deje huella duradera, que se asienten los pilares de una obra futura que puede ser planificada (ya que es fruto de una lógica científica, es decir secuenciada en proyectos), no puede ser prevista (en la medida en que depende del efecto social del reconocimiento del público lector), pero sí presentida en las palpitaciones de un habitus intelectual muy bien arraigado. Había que bajar la guardia y enviar a publicar. Aún sin estar convencida, lo hizo. El 6 de mayo, en su último mensaje de Wats app hacia mí, escribió: "Sí Gus, estoy contenta"; respuesta ante mi "bravo" con el que la felicitaba por haber pasado el umbral hacia el universo de las publicaciones, con tres envíos en simultáneo. Había enviado un texto sobre Jacques Derrida a El Taco en la Brea, hermosa publicación de estudios literarios y crítica cultural de la UNL, otro trabajo sobre la cultura escrita en la U.C.R. a Políticas de la Memoria, la reputada publicación que anima el Cedinci y un tercer artículo a nuestra RMA. A los pocos días enviamos a evaluar el artículo "literatura y política". Los positivos juicios de los pares llegaron después del fatal "accidente". Creímos entonces que era justo completar el proceso editorial, interviniendo lo menos posible en aspectos sugeridos por los evaluadores.

En el fragor de las luchas por la demanda de justicia, Carlos Viñolo, el papá de Sol, me acercó impreso uno de tantos textos escritos por Sol por mi desconocidos: "Por una antropología de lucha y sangre". El dolor me atravesaba; no podía ver noticias sobre el "accidente", tampoco leer a la querida colega y amiga. Cuando al fin pude hacerlo, me sorprendí, me maravillé. Lo mismo sucedía a cada parte de tesis, informe o breve ensayo que Sol me mandaba por mi función de director de tesis. Ya había comenzado a escribir la de doctorado sobre la poesía trans. Más audacia, innovación, sutilezas, experimentación, acciones que hacen a "lo intelectual", categoría que el genial Jack Goody definió como la acción que aún en sociedades preletradas protagonizan individuos que abren el sistema cultural, lo pensable, al introyectar nuevas asociaciones conceptuales, nuevos diagramas simbólicos. Como encarnación exacta de su nombre, ella dejaría ver su estela en la política y en la cultura como intelectual sagaz, incisiva y también cálida. "Por una antropología de lucha y sangre" dialoga con "la sociología de cuerpo y sangre" propuesta por Loïc Wacquant (cuya traducción, realizada por Paul Hatazy, editamos en el número 12 (1) de 2019), con la "afectación" en el trabajo etnográfico que propone Jaenne Favret-Saada. Es un breve ensayo de pura reflexividad, un texto en primera persona en el que explora las razones de la elección de los referentes empíricos que gravitaban en sus proyectos: la literatura, la política, el Partido Obrero. Repasa aspectos biográficos que dan cuenta de su origen social, recuerdos de la más tierna infancia y los avatares de cómo la antropología le permitió el reencuentro con una historia familiar de militancias que la marcó a fuego. No nos hubiéramos dado la libertad de añadir este otro texto al artículo "Literatura y política", si no fuera por el modo de perfecto encaje entre ambas piezas, como anticipación metodológica para que el lector comprenda no solo cómo Sol realizó su propia investigación, sino también su capacidad para dialogar con lo mejor del pensamiento universal que extiende los bordes de nuestra ciencia, de nuestras culturas. 
Muchas son las prácticas sociales que permiten la reproducción del recuerdo. Para ello ninguna tecnología logra lo que la edición. A futuro, en otros medios, esperamos disponer de las condiciones para que una selección de las decenas de manuscritos de Sol Viñolo forme un libro que extienda las intensiones de conocer tantas facetas de un ser extraordinario que a través de su lectura permanecerá no apenas entre nosotros. 